\title{
Methodological considerations on descriptive studies of induced periodontal diseases in rats
}

\section{Considerações metodológicas sobre estudos descritivos de doença periodontal induzida em ratos}

\author{
Mariane Ponzio de Azevedo Galvão* \\ Ana Chapper** \\ Cassiano Kuchenbecker Rösing*** \\ Maria Beatriz Cardoso Ferreira**** \\ Maria Antonieta Lopes de Souza*****
}

\begin{abstract}
The aim of this study was to show the technique and the methodological approach used in describing histological characteristics of induced periodontal disease in rats. To reach that inflammatory process, periodontal disease was induced by ligature, with or without sucrose-rich diet. Twenty-four female adult (60 days old) Wistar rats were divided in four groups: Group 1, or control (which received standard diet), Group 2 (which received ligature around the upper second molars and a standard diet), Group 3 (which received a sucrose-rich diet), and Group 4 (which received ligature around the upper second molars and a sucrose-rich diet). The animals were followed for a period of 30 days, after which they were sacrificed. The upper second molars were removed, processed, and the histological characteristics were analyzed by a descriptive dichotomous method. The results were analyzed by the Fisher's exact test (significance level of 95\%) and by a residual test, which showed the relation between groups and histological characteristics. The animals which received ligature (Groups 2 and 4) showed histological characteristics related with periodontitis, whilst the animals without ligatures showed no periodontal destruction. This was shown by a distribution of these groups in extremes of a graphic representation. The use of a ligature, as done in this study, was able to promote a chronic inflammatory process in the periodontium of rats, regardless of the adopted diet. The correspondence factorial analysis was capable of showing these characteristics, being one more tool to be used in histological research.

DESCRIPTORS: Factor analysis, statistical; Periodontitis; Ligation; Rats; Histology.
\end{abstract}

RESUMO: O objetivo do presente estudo foi apresentar a técnica e um método de descrição das características histológicas da doença periodontal induzida em ratos. Fez-se indução de periodontite com uso de ligaduras, com ou sem dieta rica em sacarose. Vinte e quatro ratos Wistar fêmea adultos (60 dias) foram divididos em quatro grupos: Grupo 1, ou controle (recebeu dieta padrão), Grupo 2 (recebeu ligadura ao redor dos segundos molares superiores e dieta padrão), Grupo 3 (recebeu dieta rica em sacarose) e Grupo 4 (recebeu ligadura ao redor dos segundos molares superiores e dieta rica em sacarose). Os animais foram acompanhados por um periodo de 30 dias, ao final do qual foram sacrificados. Os segundos molares superiores foram removidos e processados; fez-se análise histológica por método descritivo, dicotômico. Os resultados foram analisados pelo teste exato de Fisher (nivel de significância de 95\%) e pelo teste do resíduo, que mostrou a relação entre grupos e características histológicas. Os animais com ligadura (Grupos 2 e 4) mostraram características histológicas de periodontite, enquanto animais sem ligaduras não apresentaram sinais de destruição periodontal. O uso de ligaduras, no presente estudo, foi capaz de promover processo inflamatório crônico nos ratos, independentemente do tipo de dieta. A análise fatorial de correspondência serviu como método para mostrar tais caracteristicas, sendo mais uma ferramenta para uso em pesquisa básica.

DESCRITORES: Análise fatorial; Periodontite; Ligadura; Ratos; Histologia.

\section{INTRODUCTION}

Periodontal diseases are inflammatory processes caused by bacterial infection, which promote an orchestrated sequential host response $\mathrm{e}^{8,12}$. The prevalence of periodontal diseases, among dif- ferent world populations, is high and has an important impact in oral health programs. Since people tend to live longer, and to retain their teeth until older ages, a greater occurrence of periodontitis may be expected.

\footnotetext{
*Professor, Discipline of Periodontics, Gama Filho University.

**Professor, Discipline of Periodontics, Lutheran University of Brazil.

*** Professor, Discipline of Periodontics; ${ }^{* * *}$ Professor, Department of Pharmacology - Federal University of Rio Grande do Sul $* * * * *$ Professor, Pontifical Catholic University of Rio Grande do Sul.
} 
Galvão MP de A, Chapper A, Rösing CK, Ferreira MBC, Souza MAL de. Methodological considerations on descriptive studies of induced periodontal diseases in rats. Pesqui Odontol Bras 2003;17(1):56-62.

Experimental animal models have been proposed for the study of periodontal diseases. Two different main types of periodontal diseases have been thoroughly studied: gingivitis and periodontitis $^{12}$. Rodents are very often used for those purposes $^{4,5,6,7,10,11,13,14,15,16}$. More precisely, rats are useful in the study of periodontal diseases for offering some advantages such as price, handling and others. The microbiological evaluation is achievable and histological examination is possible ${ }^{6,10}$. In addition, the clinical, radiographic and histological aspects of periodontal diseases in rats are somewhat similar to those observed in humans. Histologically, some pathological changes as ulceration, apical migration of epithelial attachment and inflammatory infiltrate can be recognized. Collagen fiber destruction and osteoclastic activity can also be observed ${ }^{6,10}$. Induction of periodontal disease in rats has been mainly performed by three pathways: (i) inoculation of periodontopathogens, which has been extensively studied, having the features of a single infection, somewhat different from what occurs in humans ${ }^{12}$; (ii) placement of a ligature around the cervix of the tooth, which enables subgingival microorganisms to accumula te $\mathrm{e}^{4,5,7,13,15,16}$; and (iii) feeding the animals with a supragingival plaque-promoting soft diet, in order to naturally accumulate supragingival plaque on the dentogingival area ${ }^{9,11}$. The ligature without the presence of bacteria, in germ-free rats or with the use of antibiotic, cannot induce periodontal destruction $^{13,14}$.

Some authors ${ }^{5,7,14}$ have observed presence of debris, inflammatory infiltrate, attachment loss and alveolar bone destruction in rats with ligature-induced periodontitis.

Sucrose-rich diet with the purpose of inducing periodontal diseases - gingivitis and periodontitis - has been the model used by Pilatti, Sampaio ${ }^{11}$ (1997), who found signs of gingival inflammation, and by Offenbacher et al. ${ }^{9}$ (1998), who demonstrated histological features of periodontitis.

Calibration and blindness of the examiner and the use of objective histological criteria are somewhat important to guarantee a reliable descriptive histology ${ }^{3}$. It would be interesting if the experimental studies of induced periodontal disease in rats showed appropriate descriptions of the technique used to induce it, and especially analyze the descriptive pattern of the histological conditions.

Thus, the aim of the present study was to describe the histological features of periodontal tissues in rats with ligature, being or not fed with sucrose-rich diet, and to show the use of corres- pondence factorial analysis on descriptive histological studies of induced periodontal diseases in rats.

\section{MATERIAL AND METHODS Description of the sample}

Twenty-four experimentally naive adult female Wistar rats (60 days old; weighing 144-170 g) were divided in four equal experimental groups. They were maintained in a controlled environment (lights on between 07:00 a.m. and 07:00 p.m., temperature of $22 \pm 2^{\circ} \mathrm{C}$ ) for at least 1 week before and throughout the experimental period. Food and water were available ad libitum.

\section{Experimental groups}

- Group 1 (control). The animals received standard rat lab chow and water.

- Group 2 (ligature-induced periodontal disease). Cotton ligatures were placed around the second upper molars and the animals received standard rat lab chow and water.

- Group 3 (sucrose-rich diet). The rats received soft sucrose-rich chow and water.

- Group 4 (ligature-induced periodontal disease plus sucrose-rich diet). The animals in this group had cotton ligatures placed around the second upper molars and received sucrose-rich chow and water.

\section{Procedures for induction of periodontal diseases}

The twelve rats of Groups 2 and 4 had a cotton ligature placed around the second upper molars, with the aim of accumulating plaque and developing periodontitis ${ }^{5}$.

The placement of the ligature was done with general anesthesia. All the rats (including animals from Groups 1 and 3, which did not receive ligature placement) were anesthetized with sodium thiopental $(50 \mathrm{mg} / \mathrm{kg}$ of body weight, IP).

Using two Castro-Viejo needle holders, the ligature was introduced in the proximal spaces surrounding the tooth and two knots were done on the palatal surface. The ligatures were kept during 30 days and checking of their presence was done once a week. If any had been lost, it was replaced.

\section{Diet}

Standard lab chow (Supra ${ }^{\circledR}$, Alisul, Maringá, Paraná, Brazil) fed rats from Groups 1 and 3. Rats from Groups 2 and 4 received a sucrose-rich diet, composed of $53 \%$ sucrose, $30 \%$ dry milk with vitamins (Nestlé ${ }^{\circledR}$, Leite Ninho, Dairy Partners Ameri- 
Galvão MP de A, Chapper A, Rösing CK, Ferreira MBC, Souza MAL de. Methodological considerations on descriptive studies of induced periodontal diseases in rats. Pesqui Odontol Bras 2003;17(1):56-62.

can Manufacturing Brazil Ltda., Ituiuba, MG, Brazil), $14 \%$ standard powder chow, $2 \%$ mineral salts and $1 \%$ proteins. This diet was soft to prevent from self cleaning during mastication ${ }^{14}$.

\section{Histological procedures}

After 30 days of periodontal disease induction, the rats were sacrificed (under general anesthesia with ether), the maxillae were removed, fixed, decalcified with $5 \%$ nitric acid, and sectioned serially in the mesiodistal direction. The $5 \mu \mathrm{m}$ sections were stained with hematoxylin and eosin.

Descriptive histological analysis was carried out by a trained examiner who was blind to the groups. The histological features of 220 histological pieces (60 from each of Groups 1 and 2, 50 from each of Groups 3 and 4) were evaluated in the light microscope. The analysis was based on $18 \mathrm{di}-$ chotomous histological characteristics, shown in Table 1.

The histological sections were photographed using an Examet camera, model PES-A-35, Union Optical Co Ltd, Tokyo, Japan, with a colorful 100 wings film, 35 mm - Kodak (Kodak da Amazônia Indústria e Comérico Ltda., Manaus, AM, Brazil).

\section{Ethical considerations}

This project was submitted to and accepted by the registered Ethics Committees of the institutions involved.

\section{Statistical analysis}

The statistical analysis was done using correspondence analysis. The groups were compared for each histological characteristic using the Pearson chi-square test or the Fisher's exact test, using the exact test procedures of the SPSS 8.0, for Windows. Also the adjusted residuals for the contingency tables were obtained and interpreted ${ }^{2}$. All tests were done by the software SPSS (SPSS Inc., Chicago, IL, USA).

\section{RESULTS}

One animal from Group 3 and one from Group 4 were lost during the experiment.

TABLE 1 - Dichotomous histological characteristics.

\begin{tabular}{|c|c|c|}
\hline & Histological characteristic & Histological condition \\
\hline $\mathrm{C} 1$ & Junctional epithelium & Apical migration / standard dimensions \\
\hline $\mathrm{C} 2$ & Supragingival connective tissue cells & Standard quantity / overabundance \\
\hline $\mathrm{C} 3$ & Supragingival connective tissue vessels & Standard quantity / overabundance \\
\hline $\mathrm{C} 4$ & Supracrestal periodontal ligament fibers & Dense / loose \\
\hline $\mathrm{C} 5$ & $\begin{array}{l}\text { Supracrestal periodontal ligament fibers in relation to in- } \\
\text { flammatory cells and blood vessels }\end{array}$ & Standard quantity / overabundance \\
\hline C6 & Alveolar bone crest & Regular shape / irregular shape \\
\hline $\mathrm{C} 7$ & Alveolar bone crest & Presence / absence of Howship's lacunae \\
\hline $\mathrm{C} 8$ & Alveolar bone crest & Presence / absence of clastic cells \\
\hline C9 & Alveolar bone crest & Presence / absence of blastic cells \\
\hline $\mathrm{C} 10$ & Bone insertion & Presence / absence of Howship's lacunae \\
\hline $\mathrm{C} 11$ & Bone insertion & Presence / absence of clastic cells \\
\hline $\mathrm{C} 12$ & Bone insertion & Presence / absence of blastic cells \\
\hline $\mathrm{C} 13$ & Periodontal ligament cells & Standard quantity / overabundance \\
\hline $\mathrm{C} 14$ & Periodontal ligament vessels & Standard quantity / overabundance \\
\hline $\mathrm{C} 15$ & Periodontal ligament fibers & Dense / loose \\
\hline $\mathrm{C} 16$ & Root cementum & Presence / absence of Howship's lacunae \\
\hline $\mathrm{C} 17$ & Root cementum & Presence / absence of clastic cells \\
\hline $\mathrm{C} 18$ & Bone sequestrum & Presence / absence \\
\hline
\end{tabular}


Galvão MP de A, Chapper A, Rösing CK, Ferreira MBC, Souza MAL de. Methodological considerations on descriptive studies of induced periodontal diseases in rats. Pesqui Odontol Bras 2003;17(1):56-62.

Figure 1 shows histological sections of each of the groups in the study.

It was observed that all rats from Groups 1 and 3 (without ligature) showed intact junctional epithelium, with normal conformation. On the other hand, the rats from Groups 2 and 4 (with ligature) showed ruptured junctional epithelium, with flattened conformation and pegs. All rats from Groups 1 and 3 showed standard dimensions of junctional epithelium, standard quantity of connective tissue cells and blood vessels, dense supracrestal and periodontal ligament fibers, regular alveolar bone crest, standard quantity of periodontal ligament cells, and absence of Howship's lacunae in cementum, showing also standard quantity of periodontal ligament vessels, cells and vessels around supracrestal fibers, absence of alveolar bone crest, bone insertion, clasts in cementum, and sequestrum, as shown in Table 2. All rats from Groups 2 and 4 showed long junctional epithelium, overabundance of connective tissue cells and blood vessels, loose supracrestal and ligament fibers, irregular alveolar bone crest, overabundance of periodontal ligament cells, and presence of Howship's lacunae in cementum. The majority showed overabundance of periodontal ligament vessels, cells and vessels around supracrestal fibers, presence of alveolar bone crest, bone insertion, clasts in cementum, and sequestrum, as shown in Table 2 (Fisher's exact test, $\mathrm{p}<0.01$ ).

Figure 2 shows graphically the results of correspondence analysis. The variables were distributed in two extremes, so that histologically normal tissue characteristics are concentrated on the right side of the graphic, whilst the characteristics of inflammatory tissue are concentrated on the other side of the graphic.

In Figure 2, we may observe that the groups are also distributed in two different extremes of the graphic. Animals from Groups 1 and 3 are on the right side of the graphic, while animals from Groups 2 and 4 are on the opposite side. The variables for non-destroyed tissue are related to Groups 1 and 3 . The variables for destroyed tissue are related to Groups 2 and 4.

\section{DISCUSSION}

In this study, Groups 2 and 4 (ligature; ligature and sucrose-rich diet) showed histological characteristics of periodontitis. There were rupture and presence of apical migration of the junctional epithelium, profuse inflammatory cells and vessels in the connective tissues, loose periodontal ligament fibers, alveolar bone resorption, cementum rupture, and occasionally the presence of bone sequestrum. These features were also shown by other authors s $^{4,5,7,13,15,16}$.

Two previous studies suggested that inflammatory processes induced by ligature are caused by microbial infection. Rovin et al. ${ }^{13}$ (1966) observed that the use of ligature in germ-free rats was not capable of developing periodontal diseases. Sallay et al. $^{14}$ (1982) did not see periodontal destruction when ligature was combined with antibiotics.

In this study, the sucrose-rich diet used with no ligatures was not capable of promoting more inflammation than that seen in the control group. This finding is different from what was observed by
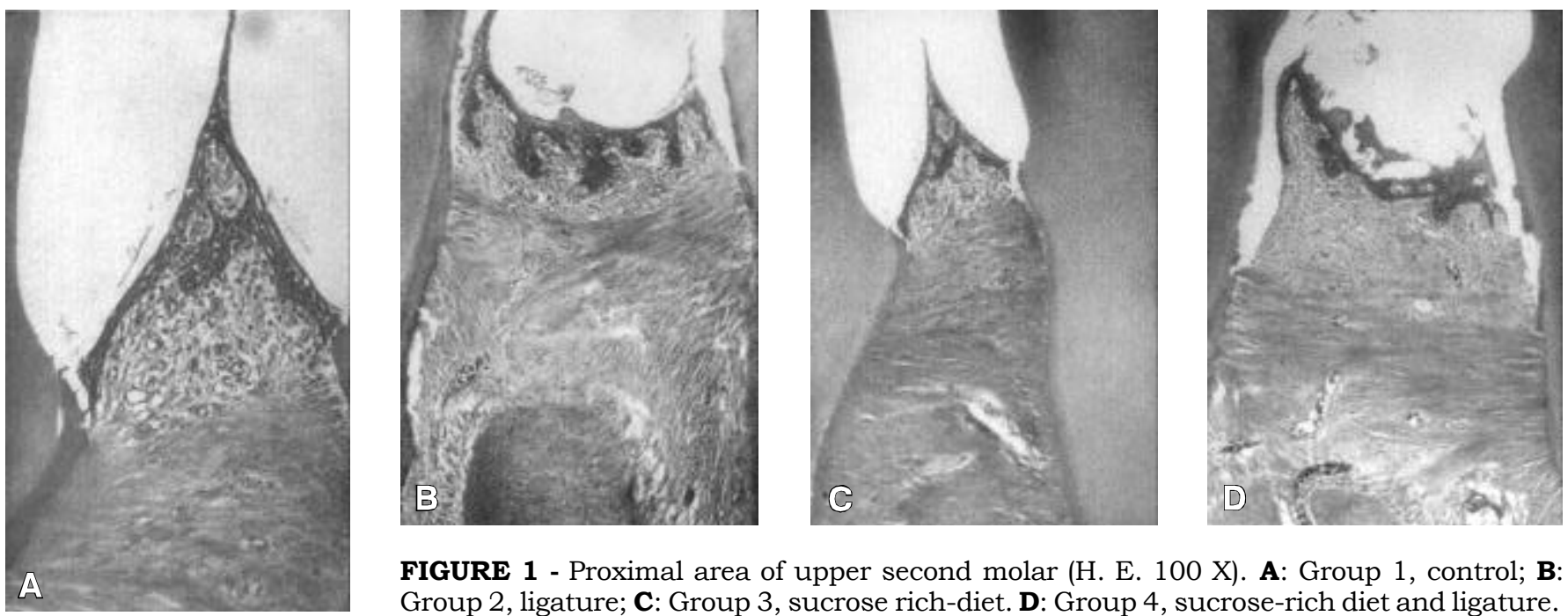

FIGURE 1 - Proximal area of upper second molar (H. E. 100 X). A: Group 1, control; B: Group 2, ligature; C: Group 3, sucrose rich-diet. D: Group 4, sucrose-rich diet and ligature. 
Galvão MP de A, Chapper A, Rösing CK, Ferreira MBC, Souza MAL de. Methodological considerations on descriptive studies of induced periodontal diseases in rats. Pesqui Odontol Bras 2003;17(1):56-62.

TABLE 2 - Histological characteristics according to the groups evaluated (percentage of animals in parenthesis).

\begin{tabular}{l|c|c|c|c}
\hline \hline \multicolumn{1}{c|}{ Characteristics } & $\begin{array}{c}\text { Group 1 } \\
\text { (control) } \\
\mathrm{n}=6\end{array}$ & $\begin{array}{c}\text { Group 2 } \\
\text { (ligature) } \\
\mathrm{n}=6\end{array}$ & $\begin{array}{c}\text { Group 3 } \\
\text { (sucrose diet) } \\
\mathrm{n}=5\end{array}$ & $\begin{array}{c}\text { Group 4 } \\
\text { (ligature plus sucrose diet) } \\
\mathrm{n}=5\end{array}$ \\
\hline $\begin{array}{l}\text { Cells and vessels around supra- } \\
\text { crestal fibers, quantity (C5) }\end{array}$ & $\begin{array}{c}\text { Standard } \\
(100 \%)\end{array}$ & $\begin{array}{c}\text { Overabundant } \\
(100 \%)\end{array}$ & $\begin{array}{c}\text { Standard } \\
(80 \%)\end{array}$ & $\begin{array}{c}\text { Overabundant } \\
(100 \%)\end{array}$ \\
\hline $\begin{array}{l}\text { Alveolar bone crest - Howship's } \\
\text { lacunae (C7) }\end{array}$ & $\begin{array}{c}\text { Absent } \\
(100 \%)\end{array}$ & $\begin{array}{c}\text { Present } \\
(100 \%)\end{array}$ & $\begin{array}{c}\text { Absent } \\
(66.66 \%)\end{array}$ & $\begin{array}{c}\text { Present } \\
(60 \%)\end{array}$ \\
\hline Alveolar bone crest - clasts (C8) & $\begin{array}{c}\text { Absent } \\
(100 \%)\end{array}$ & $\begin{array}{c}\text { Present } \\
(100 \%)\end{array}$ & $\begin{array}{c}\text { Absent } \\
(100 \%)\end{array}$ & $\begin{array}{c}\text { Present } \\
(80 \%)\end{array}$ \\
\hline Bone insertion - Howship's lacu- & $\begin{array}{c}\text { Absent } \\
(100 \%)\end{array}$ & $\begin{array}{c}\text { Present } \\
(100 \%)\end{array}$ & $\begin{array}{c}\text { Absent } \\
(100 \%)\end{array}$ & $\begin{array}{c}\text { Present } \\
(60 \%)\end{array}$ \\
\hline nae (C10) & $\begin{array}{l}\text { Absent } \\
(100 \%)\end{array}$ & $\begin{array}{c}\text { Present } \\
(100 \%)\end{array}$ & $\begin{array}{c}\text { Absent } \\
(66.66 \%)\end{array}$ & $\begin{array}{c}\text { Present } \\
(80 \%)\end{array}$ \\
\hline Bone insertion- clasts (C11) & $\begin{array}{c}\text { Absent } \\
\text { Bone insertion - blasts (C12) }\end{array}$ & $\begin{array}{c}\text { Present } \\
(100 \%)\end{array}$ & $\begin{array}{c}\text { Absent } \\
(80 \%)\end{array}$ & $\begin{array}{c}\text { Present } \\
(100 \%)\end{array}$ \\
\hline Periodontal ligament vessels- & $\begin{array}{c}\text { Standard } \\
\text { quantity (C13) }\end{array}$ & $\begin{array}{c}\text { Overabundant } \\
(100 \%)\end{array}$ & $\begin{array}{c}\text { Standard } \\
(80 \%)\end{array}$ & $\begin{array}{c}\text { Overabundant } \\
(100 \%)\end{array}$ \\
\hline Cementum - clasts (C17) & $\begin{array}{l}\text { Absent } \\
(100 \%)\end{array}$ & $\begin{array}{c}\text { Present } \\
(100 \%)\end{array}$ & $\begin{array}{c}\text { Absent } \\
(100 \%)\end{array}$ & $\begin{array}{c}\text { Present } \\
(60 \%)\end{array}$ \\
\hline \hline
\end{tabular}

Offenbacher et al. ${ }^{9}$ (1998) and Pilatti, Sampaio ${ }^{11}$ (1997). Anyhow, the presence of some level of inflammation might be an indication of the response to the constant challenge by bacteria that normally colonize the sulci.

In the present work, a period of 30 days for periodontal disease induction was used. During this period, the ligatures were maintained around the molars, acting as a local irritant. Based on the histological sections, it was observed that 30 days of induction were enough to promote inflammation and periodontal destruction. It was found that 49 days of periodontitis induction by the presence of a nylon ligature were necessary to promote osteoclastic action ${ }^{5}$. After 63 days, apical migration of junctional epithelium was seen. Signs of inflammation, lymphocytes and epithelium hiperplasia after 8 days of ligature insertion were observed ${ }^{4}$. Johnson $^{5}$ (1975) observed alveolar bone crest resorption and inflammatory infiltrate within 17 days of insertion of a silk ligature. The presence of moderate inflammatory infiltrate was found 3 days after the insertion of the ligature ${ }^{7}$.

The statistical analysis by the residual and Fisher's exact tests, Monte Carlo method, represented graphically by the factorial correspondence analysis, showed the clear distribution of inflammatory and especially periodontal destruction features related to the presence of ligatures. Few animals from Group 1 and 3 showed some blast cells and clast cells, which may not be related to inflammation, but may be related to the physiological plastic processes of osseous end cementum tissues. The use of correspondence analysis as a tool to elucidate histological features proved to be interesting when comparing groups. The use of these tests may help the reader to graphically observe what is really going on in the tissues. This may be combined with blindness and calibration of the examiner, creating better chances of a more objective view of subjective parameters, which are a great part of new paradigms in medical research. Correspondence analysis may, thus, be considered a good method to analyze histological changes.

The use of ligature, as done in this study, was able to promote periodontitis in rats, regardless of the diet. The gingiva of the animals fed with sucrose-rich diet did not differ from that of the controls. The correspondence factorial analysis seems to be an adequate tool to measure (evaluate) histological characteristics of induced periodontal diseases. 
Galvão MP de A, Chapper A, Rösing CK, Ferreira MBC, Souza MAL de. Methodological considerations on descriptive studies of induced periodontal diseases in rats. Pesqui Odontol Bras 2003;17(1):56-62.

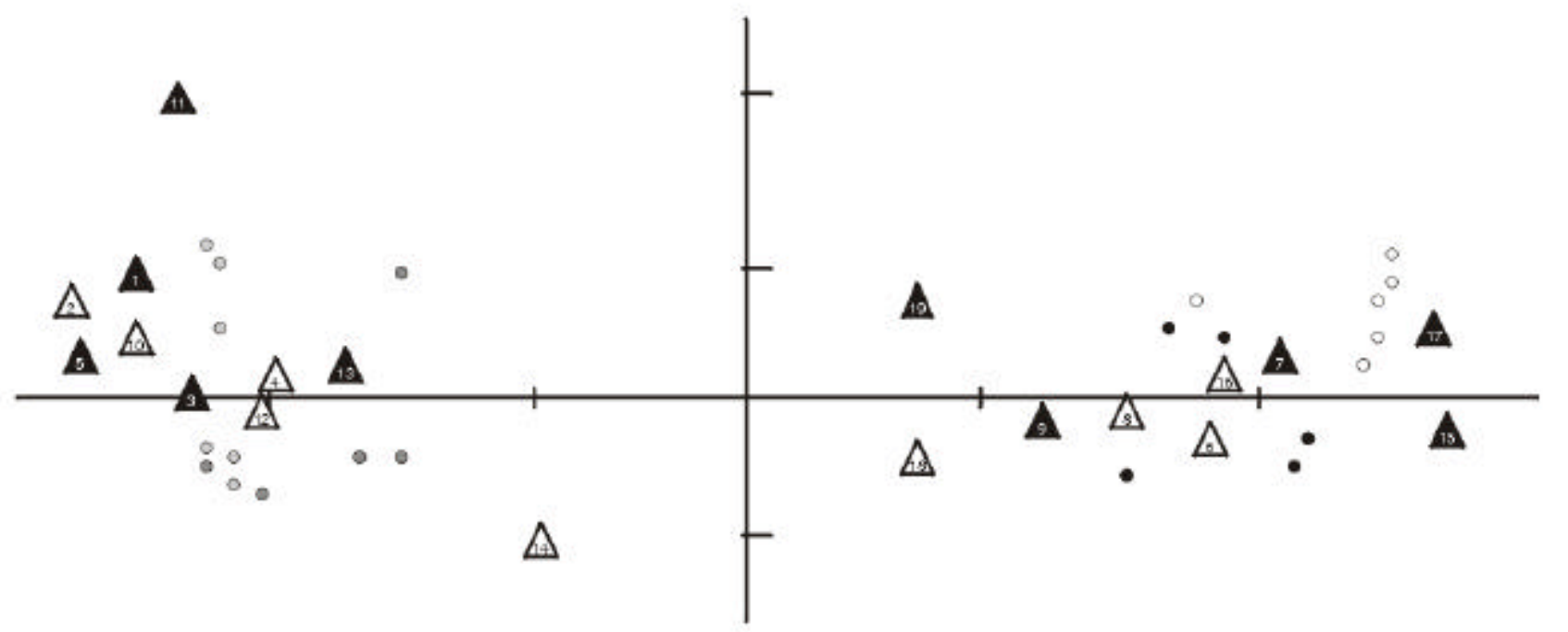

- Animals from Group 1, control

- Animals from Group 2, ligature

A Presence of clasts and Howship's lacunae, bone insertion and alveolar bone crest.

A Howship's lacunae in cementum.

A. Bone crest with irregular formation, bone insertion with clasts.

$\triangle$ Supracrestals periodontal ligament fibers with inflammatory cells.

A Presence of bone sequestrum.

A Connective inflammatory cells and blood vessels in standard quantity.

A. Standard quantity of inflammatory cells and blood vessels of supracrestal and periodontal ligaments.

A Alveolar bone crest with normal conformation.

A. Alveolar bone crest without clasts and Howship's lacunae.
- Animals from Group 3, sucroserich diet

- Animals from Group 4, sucrose-rich diet and ligature

A Periodontal and supracrestals periodontal ligament fibers loosen and overabundance of inflammatory cells in periodontal ligament.

Ai. Connective blood vessels in overabundance.

A Connective inflammatory cells in overabundance.

Appical migration of junctional epithelium.

A Bone insertion without blasts.

A. Normal dimensions of junctional epithelium, entire and with normal conformation.

A. Cementum and bone insertion without clasts.

Insertion bone without Howship's lacunae.

Absence of bone sequestrum.

Bone insertion with blasts.

FIGURE 2 - Descriptive representation of histologic characteristics of interproximal areas in upper molars of rats from different groups, by correspondence analysis. 
Galvão MP de A, Chapper A, Rösing CK, Ferreira MBC, Souza MAL de. Methodological considerations on descriptive studies of induced periodontal diseases in rats. Pesqui Odontol Bras 2003;17(1):56-62.

\section{REFERENCES}

1. Albandar JM, Rams TE. Global epidemiology of periodontal diseases: an overview. Periodontol 2000 2002;29:7-10.

2. Everitt BS. The analysis of contingency tables. London: Chapman \& Hall; 1992.

3. Fletcher RH, Fletcher SW, Wagner EH. Clinical epidemiology: the essentials. Baltimore: Williams \& Wilkins; 1996.

4. Györfi A, Fazekas Á, Suba ZS, Ender F, Rosivall L. Neurogenic component in ligature-induced periodontitis in the rat. J Clin Periodontol 1994;21:601-5.

5. Johnson JH. Effects of local irritation and dextran sulphate administration on the periodontium of the rat. J Periodontal Res 1975;10:332-45.

6. Klausen B. Microbiological and immunological aspects of experimental periodontal disease in rats: a review article. J Periodontol 1991;62:59-73.

7. Koide M, Suda S, Saitoh S, Ofuji Y, Suzuki T, Yoshie H, et al. In vivo administration of IL-1 accelerates silk ligature-induced alveolar bone resorption in rats. J Oral Pathol Med 1995;24:420-34.

8. Offenbacher S, Collins J, Arnold RR. New clinical diagnostic strategies based on pathogenesis of disease. J Periodontol Res 1993;28:523-35.

9. Offenbacher S, Jared HL, O'Reilly PG, Wells SR, Salvi GE, Lawrence HP, et al. Potential pathogenic mechanisms of periodontitis associated pregnancy complications. Ann Periodontol 1998;3:233-50.

10. Page RC, Schroeder E. Periodontitis in man and other animals. Basel: Karger; 1982.

11. Pilatti GL, Sampaio JE. The influence of chlorhexidine on the severity of cyclosporine-A induced gingival overgrowth. J Periodontol 1997;68:900-4.

12. Ranney RR. Classification of periodontal diseases. Periodontol 2000 1993;2:13-25.

13. Rovin S, Costich ER, Gordon AH. The influence of bacteria and irritation in the initiation of periodontal disease in germfree and conventional rats. J Periodontal Res 1966; 1:193-204.

14. Sallay K, Sanavi F, Ring I, Pham P, Behling UH, Nowotny A. Alveolar bone destruction in the immunosuppressed rat. $\mathrm{J}$ Periodontal Res 1982;17:263-74.

15. Sanavi F, Listgarten MA, Boyd F, Sallay K, Nowotny A. The colonization and establishment of invading bacteria in the periodontium of ligature-treated immunosuppressed rats. J Periodontol 1985;56:273-80.

16. Yoshinari N, Kameyama Y, Aoyama Y, Nishiyama H, Noguchi T. Effect of long-term methotrexate-induced neutropenia on experimental periodontal lesion in rats. J Periodontal Res, 1944;29:393-400.

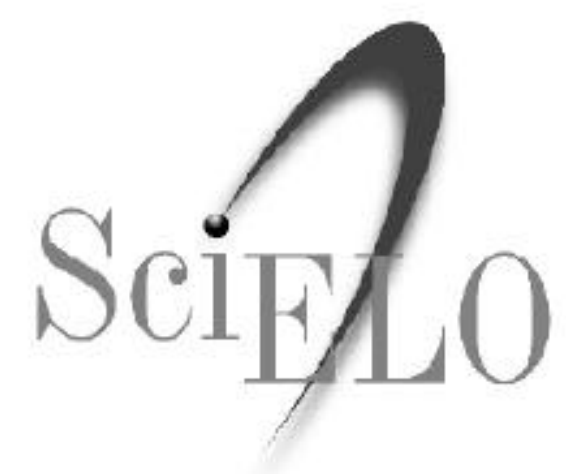

http://wuwwo.scielo.br

\section{As publicações científicas brasileiras estão ao alcance de suas mãos. Não importa em que parte do mundo você esteja.}

\author{
SciELO - Scientific Electronic Library Online é
} uma biblioteca de revistas científicas disponível na Internet. Uma biblioteca virtual que reúne 64 publicações científicas brasileiras. Sua interface permite o acesso fácil aos textos completos de artigos científicos, por meio das tabelas de conteúdos dos números individuais das revistas ou da recuperação de textos por nome de autor, palavras-chaves, palavras do título ou do resumo. 